\title{
Assessment of Transfer of Cocoyam Technologies in Anambra State, Nigeria
}

\author{
S. O. Olatunji ${ }^{*}$, F. N. Nwakor ${ }^{2}$ and G. N. Asumugha ${ }^{2}$ \\ Received : 09th April 2015 / Accepted : $19^{\text {th }}$ July 2015
}

\begin{abstract}
Agricultural transformation can be achieved in Nigeria in the presence of an effective, well-designed and well executed system of technology development and transfer. Multistage random sampling procedure was employed to select a sample of 36 EAs from the population of all Extension Agents (EAs) in Anambra State Agricultural Development Project (ADP). Research data were collected with the aid of structured questionnaire while data were analyzed using descriptive statistics (mean, percentage, ranks) and inferential statistics (multiple regression analysis). The results of data analyses revealed low percentage of young Extension Agents and low percentage of female EAs. A few academically unqualified EAs were on the roll of Anambra State ADP. The transfer of cocoyam technologies in the State has exceeded 73\% of its target even as 17 out of 23 cocoyam technologies under study have been transferred to farmers. The major constraints to cocoyam technologies transfer relates to poor conditions of service for EAs, lack field vehicles, poor funding of extension activities, rejection of technologies by farmers on the basis of incompatibility of technologies to farmers' local practices, inadequate number EAs and poor linkage among Research/Extension/ Farmer/Input Agencies. It was recommended that vigorous efforts be put in place to transfer 6 other cocoyam technologies which were yet to be transferred to the farmers. Also, more young and female EAs should be recruited. The conditions of service of EAs should be improved and that the ideal Training and Visit system of agricultural extension be implemented while research adapt cocoyam technologies to farmers'local conditions and practices.
\end{abstract}

Keywords: Technology transfer, Cocoyam, Assessment, Agriculture, Agricultural Development Project (ADP).

\section{INTRODUCTION}

Food production in Nigeria seems to be declining over the years in spite of the fact that the population have continued to grow. Ijere (1992) explained that the rapid increase in Nigeria's population growth have continued to widen the gap between food demand and food supply. Several factors have been linked to this undesirable situation. These include: inadequate capital, land fragmentation, use of crude implements, rural-urban migration of youths, poor rural infrastructure, pests and disease outbreak, poor processing and storage facilities, inadequate technologies and ineffective agricultural extension systems (Ugwoke et al., 2005; Olatunji et al., 2014). Over the years, the
Nigerian Government predicated agricultural development on enhancing output through increased use of scientifically improved crop and animal breeds, mechanization and the expansion of cultivated areas. Efforts were focused in technology generation as a process by which improved, cost-effective and high yielding production methods were developed to enhance productivity with available resources (Ijere, 1998). The Federal Government of Nigeria established 20 Agricultural Research Institutes, one of which is National Root Crops Research Institute (NRCRI), Umudike. The NRCRI was saddled with the responsibility of research into genetic improvement of 
cassava, yam, sweet potato, ginger, tumeric and cocoyam (Oguniyan et al., 2012; Nwakor et al., 2014). According to Olatunji and Nwakor, (2015) there were at least 16 categories of root and tuber crops technologies that the NRCRI had developed. Some of these include, improved cassava varieties, improved sweet potato varieties, improved yam varieties, value addition, and improved cocoyam production. Cocoyam (colosasia sp. and xanthosoma sp.) is an important food security crop grown mostly by women in the South-Eastern, SouthSouthern and South-Western Nigeria (Ikwelle et al., 2003),

The National Root Crops Research Institute (NRCRI), Umudike had promoted colocasia and xanthosoma varieties of cocoyam with the following cultivars or species: cocoindia $(\mathrm{NCe}$ 001), edge ofe green ( $\mathrm{NCe} 002$ ), ede ofe purple ( $\mathrm{NCe} 003$ ), ede giant ( $\mathrm{NCe} 004$ ) ede upong ( $\mathrm{NCe}$ 005), ede ghana ( $\mathrm{NCe} 006)$, ede ocha $\left(\mathrm{NX}_{\mathrm{S}} 001\right)$, ede Uhie $\left(\mathrm{NX}_{\mathrm{S}} 002\right)$ and ede okorokoro $\left(\mathrm{NX}_{\mathrm{S}} 003\right)$ (Olatunji and Nwakor, 2015). It was expected that these technologies would be transferred from the research station to the end users (that is, the farmers) via the extension service. The goal of achieving agricultural transformation would be a mirage if developed technologies remain in the research stations. One way of achieving the goal of food security is to have an effective, well-conceived, well-planned and well-executed system of technology transfer. In order to have expected impact on national development, improved technologies must be made available to those in the production systems (That is, the farmers). Transfer of technology is usually the responsibility of the agricultural extension service. Against this background, it was pertinent ascertain the extent to which the cocoyam technologies developed by the NRCRI, Umudike, has been transferred to farmers in Anambra State. The objectives of the study were to:
1. examine the socio-economic characteristics of Extension Agents in the area of study.

2. ascertain cocoyam technologies that had been transferred to farmers in the study area.

3. determine constraints to transfer of cocoyam technologies.

4. determine factors that were significantly affecting technology transfer in the study area.

\section{METHODOLOGY}

The study was conducted in Anambra State Agricultural Development Project (ADP) in Nigeria. Anambra State is one of the states in the South-Eastern Ecological zones being serviced by the National Root Crops Research Institute (NRCRI), Umudike. The NRCRI was established to particularly focus on relevant root and tuber crops technologies for the zone. The NRCRI developed cocoyam technologies for dissemination to its mandate South-Eastern States farmers in particular and the entire country at large. The study was conducted with a view to assessment of the extent to which the NRCRI, Umudike has achieved its goal of developing root and tuber crops technologies for dissemination to its immediate environment. The population of study comprised all Extension Agents (EAs) in the ADP of Anambra State. There are 4 ADP zones with about 128 EAs. Multistage sampling procedure was employed. The sampling procedure recognized the administrative and professional stratification of ADPs into Zones, Blocks and Circles. The first stage involved simple random sampling of 2 out of 4 Zones. The second stage also involved simple random sampling of 3 Blocks per Zone while the last stage employed stratified random sampling of 6 circles (each manned by one EA) from selected Blocks. In all the sample comprised 36 Extension Agent. Structured questionnaire was used to collect relevant research data. Data were 
analyzed using descriptive statistics (means, percentage and ranking) and inferential statistics (regression). Objective 4 which is determining the factors affecting technology transfer was analyzed by Ordinary Least Square (OLS) and Multiple Regression Analysis. Four functional (Linear, Semi log, Double log and Exponential functions forms) were tried. The model was specified implicitly thus:

$\mathrm{Y}=\mathrm{f}\left(\mathrm{X}_{1}, \mathrm{X}_{2}, \mathrm{X}_{3}, \mathrm{X}_{4}, \mathrm{X}_{5}, \mathrm{X}_{6}, \mathrm{X}_{7}, \mathrm{X}_{8}, \mathrm{X}_{9}, \mathrm{X}_{10, \mathrm{U}) \ldots \ldots \ldots(1)}\right.$

Where,

$\mathrm{Y}=$ Number of technologies transferred ( in numbers)

$\mathrm{X}_{1}=$ Number of visits (in months)

$\mathrm{X}_{2}=$ Non availability of funds (in Naira)

$\mathrm{X}_{3}=$ Complexity of technology $(\mathrm{yes}=0, \mathrm{no}=0)$

$\mathrm{X}_{4}=$ Educational status (in years)

$\mathrm{X}_{5}=$ Numbers of communities /individuals covered ( in numbers)

$\mathrm{X}_{6}=$ Mean distance to farmers home (in $\mathrm{km}$ )

$\mathrm{X}_{7}=$ Availability of field car/motor cycle (available $=1$, not available $=0$ )

$\mathrm{X}_{8}=$ Poor condition of service $(\mathrm{Yes}=1, \mathrm{No}=0)$

$\mathrm{X}_{9}=$ Extension teaching method used (group contact $=1$, individual contact $=0$ )

$\mathrm{X}_{10}=$ Poor extension farmer's linkage (Yes $=1$, No $=0$ )

$\mathrm{U}=$ Error term

\section{RESULTS AND DISCUSSION}

The results of data analyses were presented in frequency Tables and discussed in the paragraphs that follow:

\section{Socio-economic characteristics of Extension Agents in Anambra State ADP}

The results of data analyses in Table 01 revealed that $8.3 \%$ of the respondents aged below 30 or 30 years. There were $58.3 \%$ and $33.4 \%$ in the age ranges of 31-40 and 41-50 respectively. None of the Extension Agent was above 50 years of age. Although respondents were generally not too old as to have their productivity under suspect, the percentage inclusion of young people appeared to be too low. Jibowo and Sotomi (1996) had explained that youths are characterized by innovative proneness, minimal risk aversion, greater physical strength and less conservatism. Youths are key agents for social change and economic development of the nation. There is the need to enlist the participation of more youths in Nigeria's agricultural development.

Data in Table 01 revealed that $77.8 \%$ of the respondents were males while only $22.2 \%$ were females. Studies have shown that more women than men are engaged in agricultural in Nigeria, and that females were under-represented in the number of Agricultural Extension Agents and Reprehensive Content Farmers (Olatunji, et al 2014). There are cultural and religious barriers to open and public interaction between males and females. The implication is that more female EAs are required to bridge the gap and ensure that female farmers are getting adequate information about cocoyam technologies.

It can also be noted that about $63.8 \%$ and $30.6 \%$ of respondents have OND/HND, and B.Sc certificates. While it is commendable that more than $94 \%$ were academically qualified, the $5.6 \%$ that were not qualified should be retrained or dropped. In terms of work experience, $33.3 \%$, $25.0 \%, 16.7 \%$ and $25.0 \%$ had $10,11-20,21-$ 30 and above 30 years of job experience. The implication is that majority of the respondents have adequate work experiences and are expected to make significant professional impact. 
Table 01: Percentage distribution of respondents on the basis of their socio-economic characteristics

\begin{tabular}{lcc}
\hline \multicolumn{1}{c}{ Characteristics } & Frequency & Percentage \\
\hline Age & 3 & \\
$\leq 30$ & 21 & 8.3 \\
$31-40$ & 12 & 58.3 \\
41.50 & - & 33.4 \\
$\geq 51$ & & 0.0 \\
Sex & 28 & \\
$\quad$ Male & 8 & 77.8 \\
Female & & 22.2 \\
& & \\
Marital status & 34 & \\
Married & 2 & 94.4 \\
Not married & & 5.6 \\
Highest educational qualification & 2 & \\
WASC, NECO, NCE & 23 & 5.6 \\
OND/HND & 11 & 63.8 \\
B.Sc & - & 30.6 \\
MSc & - & - \\
PhD & & - \\
Work experience & 12 & 33.3 \\
$\leq 10$ years & 9 & 25.0 \\
$11-20$ & 6 & 16.7 \\
21-30 & 09 & 25.0 \\
$\geq 31$ & & \\
\hline
\end{tabular}

\section{Cocoyam technologies that have been transferred to farmers in the study area}

As shown in Table 02, respondents agreed that 17 out of the 23 (representing 73.9\%) of cocoyam species and technologies under study have been transferred to farmers. It is commendable that much of the cocoyam technologies from the NRCRI, Umudike has been transferred to farmers in Anambra State. This is may be an indication that the Research/ Extension/Farmer/Input Agencies linkage was effective in the State. Agricultural Extension has been described as the kingpin in the process of technology generation, technology transfer It should be noted however, that the mean technology transfer ratings were less than 2.5 for technologies such as pest control, diseases control, use of raised platform, cocoyam starch, use of fungicides and use of wood ash against pests and diseases. Efforts are needed to effectively disseminate these other 6 technologies whose transfer was found to be at low ebbs. It has been shown that an effective system of technology transfer is capable of bringing about sharp increases in agricultural productivity (Olatunji et al., 2014). and technology utilization. (Anwanane, 1990 and Ilevbaoje, 1991). 
Table 02: Mean rating of cocoyam varieties and technologies transferred to farmers

\begin{tabular}{|c|c|c|}
\hline $\mathrm{S} / \mathrm{N}$ & Cocoyam varieties and technologies & Mean rating \\
\hline 1. & cocoindia (Nce 001) & $* 3.24$ \\
\hline 2. & ede ofe green (Nce 002) & *2.81 \\
\hline 3. & ede ofe purple (Nce 003) & *3.03 \\
\hline 4. & ede giant (Nce 004) & $* 3.41$ \\
\hline 5. & ede ukpong (Nce 005) & *2.72 \\
\hline 6. & ede gana (Nce 006) & $* 2.61$ \\
\hline 7. & ede ocha $\left(\mathrm{Nx}_{\mathrm{s}} 001\right)$ & $* 2.50$ \\
\hline 8. & ede uhie $\left(\mathrm{Nx}_{\mathrm{s}} \mathrm{002}\right)$ & $* 2.54$ \\
\hline 9. & ede okorokoro $\left(\mathrm{Nx}_{\mathrm{s}} 003\right)$ & $* 2.58$ \\
\hline 10. & Recommended time of planning & *3.64 \\
\hline 11. & Improved spacing & $* 2.72$ \\
\hline 12. & Use of NPK fertilizer & $* 2.51$ \\
\hline 13. & Pest control & 1.69 \\
\hline 14. & Disease control & 1.05 \\
\hline 15 & Use of organic matter & *2.04 \\
\hline 16. & Use of raised platform storage (improved ban) & 1.68 \\
\hline 17. & Cocoyam flour & $* 2.61$ \\
\hline 18. & Cocoyam flakes & *2.63 \\
\hline 19. & Cocoyam crisps & $* 2.51$ \\
\hline 20. & Cocoyam soup thinker & $* 2.54$ \\
\hline 21. & Cocoyam stanch & 1.43 \\
\hline 22. & Use of fungicides & 1.35 \\
\hline 23 & Use of wood ash agents pests and diseases & 2.01 \\
\hline
\end{tabular}

* Mean $\geq 2.5$ is significant

\section{Constraintstotransfer of cocoyam technologies in the study area}

As shown in Table 03, poor condition of service of the Extension Agents (EAs), lack of vehicles for transportation and inadequate funds for extension activities ranked $1^{\text {th }}, 2^{\text {nd }}$ and $3^{\text {rd }}$ mean rating of $3.46,2.81$, and 2.73 respectively. The results corroborates those found by Olatunji et al., (2014) in a study of job performance and job satisfaction of EAs in Rivers State ADP. The researcher had noted that farmers' usual rejection of production recommendations, delay or denial of promotion of EAs, inadequate coverage by EAs as the major constraints to effective performance of their jobs. Should the ideal Training and Visit agricultural extension system proposed by Benor and Harrison (1977) be implemented properly, Extension Agents would not require vehicles to do their jobs. They were supposed to live within their circles of 8 congruent sub-circles. Hence, the need for vehicles would not have arisen, because they would merely require bicycle, tricycle or motor-cycle to do their jobs. 
Respondents also agreed that the following factors constitute constraints to transfer of cocoyam technologies: farmers rejection of technology on the basis that they were not compactable with their local practices, inadequate number of EAs, political instability that affects the management of the extension service, poor coordination among Research/ Extension/ Farmers/Input Agencies, large farmer-EAs ratio and the preponderance of male EAs in the extension service. Olatunji et al., (2014) in a study of extension coverage of female crop farmers in Ogba/Egbema/Ndoni Local Government Areas of Rivers State also recorded higher percentage of male than female EAs. They noted that female farmers considered the phenomenon a very limiting factor in their agricultural production efforts.

On the other hand, illiteracy among farmers, farmers' lack of interests in extension messages and lack of improved agricultural technologies were not considered serious constraints to transfer of cocoyam technologies by the respondents. The implication is that, in spite of illiteracy, farmers were still interested in extension messages.

\section{Factors that significantly affect agricultural extension activities in the area of study}

The regression results of factors affecting cocoyam technology transfer in Anambra State were presented in Table 04. The semi log form of the multiple regression was chosen as the lead equation. The $\mathrm{R}^{2}$ value of 0.854 indicates that $85.0 \%$ of the variation in the transfer of cocoyam technologies were explained by the independent variables considered in this study. The coefficient of distance covered by the Extension Agents is significant at one percent level and positively signed. on-availability of field vehicles and poor conditions of service were significance at five percent $(5.0 \%)$ level of probability and negatively signed. The number of visits by the Extension Agents, the number of time visited, the extension teaching method used and poor extension/farmers linkage were significant at ten percent levels of probability. The implication is that covering of long distances by EAs, in-availability of field vehicles, poor condition of service, extension method used and poor extension/farmer linkage were the most significant factors affecting transfer of cocoyam technologies in the area of study.

Table 03: Respondents' mean rating of constraints to transfer of cocoyam technologies

\begin{tabular}{llcc}
\hline S/N & \multicolumn{1}{c}{ Constraints to transfer of cocoyam technologies } & Mean & Rank \\
\hline 1 & Poor conditions of service for extension agents & $* 3.46$ & 1 \\
2 & Farmers' lack of internet in extension messages & 1.52 & 11 \\
3 & EAs' lack of vehicles for transportation. & $* 2.81$ & 2 \\
& Farmers' rejection of technology on the basis that they are not compatible with their & $* 2.63$ & 4 \\
$4 . \quad$ environment and local practices & $* 2.73$ & 3 \\
5. & Inadequate funds for extension activities & $* 2.51$ & 8 \\
6. & Large farmer:EAs ratio. & $* 2.53$ & 7 \\
7. & Poor coordination among research/extension/farmer/input agencies & $* 2.65$ & 5 \\
8. & Inadequate number of EAs to cover all available circles & 2.43 & 10 \\
9. & Widespread illiteracy among farmers and its attendant conservatism & $* 2.50$ & 9 \\
10 & $\quad$ Preponderance of male EAs in Extension vis-à-vis religions and cultural barriers that & $* 2.54$ & 6 \\
11 & $\quad$ Political instability that affects the management of extension service & $* 2.54$ & 12 \\
12 & Lack of improved Technologies & 1.06 & \\
\hline
\end{tabular}


Table 04: Results of regression analysis of factors affecting cocoyam technology transfer

\begin{tabular}{|c|c|c|c|c|}
\hline Variables & Linear & Double log & Semi log & Exponential \\
\hline Constant & $20.039(8.332)$ & $3.187(9.318)$ & $3.340(13.904)$ & $19.049(5.887)$ \\
\hline No of visit $\left(\mathrm{X}_{1}\right)$ & $-1.856^{* * *}(-3.625)$ & $-472^{* * *}(-2.822)$ & $-199^{* * *}(-3.899)$ & $-4.854^{* * *}(-3.070)$ \\
\hline Non availability of fund $\left(\mathrm{X}_{2}\right)$ & $-2.406(-4.111)$ & $-294^{*}(-2.095)$ & $-230^{* * *}(-3.942)$ & $-3.205^{* * *}(-2.414)$ \\
\hline Complexity of R/E process $\left(\mathrm{X}_{3}\right)$ & $0.527^{* * *}(1.109)$ & $-250^{*}(-1.794)$ & $0.055^{*}(1.149)$ & $-2.288^{*}(-1.737)$ \\
\hline Education status $\left(\mathrm{X}_{4}\right)$ & $0.252^{* * *}(1.568)$ & $400^{* * *}(3.202)$ & $0.024^{* * *}(1.502)$ & $3.898^{* *}(3.302)$ \\
\hline No communities $\left(\mathrm{X}_{5}\right)$ & $-159(-408)$ & $-299^{* * *}(-3.207)$ & $-009^{*}(-236)$ & $-2.968^{* *}(-3.369)$ \\
\hline Mean distance $\left(\mathrm{X}_{6}\right)$ & $-687(1.760)$ & $-154(-871)$ & $-088^{* *}(-2.262)$ & $-1.580(-944)$ \\
\hline Availability of field vehicles $\left(\mathrm{X}_{7}\right)$ & $2.309^{* *}(2.181)$ & $-030(-276)$ & $0.223^{*}(2.111)$ & $-449(-426)$ \\
\hline Condition of service $\left(\mathrm{X}_{8}\right)$ & $-613(-2.371)$ & $-083(-548)$ & $-056^{* *}(2.160)$ & $-630(-438)$ \\
\hline Extension teaching method $\left(\mathrm{X}_{9}\right)$ & $2.690(2.602)$ & $-194^{*}(-2.144)$ & $0.312^{* * *}(3.026)$ & $-1.899^{* *}(-2.219)$ \\
\hline Poor extension linkage $\left(\mathrm{X}_{10}\right)$ & $-1561^{* * *}(-3.018)$ & $-208(2.438)$ & $207^{* * *}(3.999)$ & $-1.526^{*}(1.892)$ \\
\hline $\mathrm{R}^{2}$ & 0.847 & 0.703 & 0.854 & 0.721 \\
\hline Adjusted & 0.729 & 0.474 & 0.742 & 0.506 \\
\hline F-Statistics & $7.186^{* * *}$ & $3.072 * *$ & $7.631 * * *$ & $0.354^{* * *}$ \\
\hline
\end{tabular}

\section{CONCLUSION AND RECOMMENDATIONS}

The percentages of young EAs that aged below 30 years and female EAs were very low in the study area. There were about 5.6\% EAs who did not have required academic qualifications on the roll of Anambra State ADP. Respondents agreed that 17 out of 23 cocoyam technologies under study has been transferred to the farmers. The major constraints to transfer of cocoyam technologies relates to poor condition of service of EAs, lack of field vehicles and poor funding of agricultural extension activities. However, respondents agreed that, in spite of widespread illiteracy, farmers were still interested in extension messages.
It was recommended that:

1. the Agricultural Extension Service should invigorate efforts at transferring the 6 cocoyam technologies which the study noted had not been effectively transferred to the end-users (farmers).

2. more youths should be recruited into the agricultural extension service as a way of encouraging them to participate in agriculture. The few unqualified EAs on the roll of Anambra State ADP should be replaced or trained while adequate number 
of EAs are recruited to reduce the current large farmer EA ratio.

3. More female EAs should be recruited so that female farmers would not be disadvantaged in the process of technology transfer. Females EAs are likely to reach out to female farmers more effectively than male EAs.

4. the Extension Service Management should improve the conditions of service of EAs. Implementation of the ideal Training and Visit (T\&V) extension system where the need for field vehicles for EAs does not arise was suggested. Under T\&V system, EAs live within their circles.

5. the NRCRI should adapt cocoyam technologies to farmers' local conditions and practices so as to remove the constraints of farmers rejecting technologies that are not compatible to their indigenous practices.

6. the linkage among research/extension/ farmers/input agencies should be strengthened

\section{REFERENCES}

Anwanane, E. B. (1990). Strengthening research and extension linkages through the Monthly Technology Review Meetings (MTRM): Akwa-Ibom State ADP experience. In: Improving small scale farmers' productivity through Research and extension: challenge for the 1990s - Proceedings of the fifth annual farming systems research and extension workshop in S. E. Nigeria. E. C. Nwagbo; F. O. Anuebunwa; R. S. O. Okoli and F. M. A. Nyiam-Bisong, (Eds). Pp.8-10.

Benor, D. and Harrison J. Q. (1977). Agricultural Extension: The Training and Visit system. The World Bank, Washington D. C., 206 pages.

Ijere, M.O. (1998). Rural youth as factor for agricultural transformation (Key note address). World food Day, Abuja: Nigeria. Pp 4-5.

Ijere, M.O. (1992) Leading issues in Nigeria Rural Development, CRDC. Nsukka: University of Nigeria.

Ikwelle, M. C., Ezulike, T. O, and Eke-Okoro, O. N. (2003) Contributions of root and tuber crops to the Nigerian economy. Proceedings of $8^{\text {th }}$ Triennial Symposium of the International Society for Tropical Root Crops-Africa Branch (IBTRC-AB) held at the International Tropical Agriculture, Ibadan, Nov.12-16, pp:13-18.

Ilevbaoje I. E. (1991) Evaluation of the training and Visit Extension system in Benue and plateau Agricultural development projects in Nigeria. Ph.D Dissertation. University of Ibadan, Ibadan, 510 pages.

Jibowo, A. A. and Sotomi, A. O. (1996). The youths in sustainable rural development: A study of youth programmes in Odeda Local Government Area of Ogun State. . In A.A. Ladele, et al, (Eds) Policy Advocacy Role in Agricultural and Rural Transformation in Nigeria. Proceedings of $17^{\text {th }}$ Annual Congress of the Nigerian Rural Sociological Association (NRSA); NRCRI, Umudike. $19^{\text {th-22 }} 2^{\text {nd }}$ August 
Ngwoke, F.O., Adesope, O.M., Ibe, F.C. (2005) Youths' participation in farming activities in rural areas of Imo State, Nigeria: Implications for extension. Journal of Agricultural Extension. $8: 136-141$.

Nwakor, F.N., Aniedu, C. and Olatunji, S.O. (2014) Assessment of transfer and adoption of root and tuber crops technologies in South Eastern Nigeria. Journal of Forestry, Environment and Sustainable Development (JOFESD). 1 (1) :

Ogunniyan, D.J., Olakojo, S.A. and Adebayo, M.A. (2012). Breeding and crop improvement in Nigeria: Prospects and Challenges. In H.M. Ijeomah and A.A. Aiyeloja (Eds) Challenges to sustainable production in agriculture and environment: Nigeria in perspective. pp. 81-104.

Olatunji, S. O.; Ifeanyi-obi, C. C. and Etuk, U. R. (2004) Extension coverage of female foodcrop farmers in Ogba/Egbema/Ndoni Local Government Area of Rivers State, Nigeria. International Journal of Applied Agricultural Research 10 (1):7-16.

Olatunji, S.O. and Nwakor, F. N. (2015) Comparative analysis of awareness and adoption of root and tuber crops technologies among farmers in Abia, Imo and Akwa-Ibom States, Nigeria. International Journal of Scientific \& Technology Research 4 (3): Accepted for publication

Olatunji, S. O.; Onumadu, F. N. and Ifeanyi-obi, C. C.(2015) Job performance and job satisfaction of agricultural Extension Agents in Rivers State Agricultural Development Project (ADP). (IOSR) Journal of Agriculture and Veterinary Science. 8(1): 50-55

Olatunji, S. O.; Unamma, R. P. A. and I. Nwachukwu (2014) Agricultural Extension Service in Nigeria: Evaluation of implementation of Unified Agricultural Extension Service in Abia and Akwa-Ibom States. Germany: LAP LAMBERT Academic Publishing (OmniScriptum GmbH\&Co. KG). 156pages

Ugwoke, F.O.; Adesope, O. M. and Ibe, F. C. (2005) Youths' participation in farming activities in rural areas of Imo State, Nigeria: Implications for extension. Journal of Agricultural Extension. 8: 136-141. 